\title{
Knowledge, Attitude, and Practice on Food Safety among Senior High School Students in Jatinangor from August-November 2013
}

\author{
Hamizah Sabrina Binti Ahamad Naina, ${ }^{1}$ Ine Kuswardinah, ${ }^{2}$ Sumartini Dewi ${ }^{3}$ \\ ${ }^{1}$ Faculty of Medicine Universitas Padjadjaran, ${ }^{2}$ Department of Microbiology and Parasitology \\ Faculty of Medicine Universitas Padjadjaran, ${ }^{3}$ Department of Internal Medicine Faculty of \\ Medicine, Universitas Padjadjaran/Dr. Hasan Sadikin General Hospital Bandung
}

\begin{abstract}
Background: Food safety is defined as the confidence level that food will not cause sickness or harm to consumer when it is prepared, served, and eaten according to its intended use. This study was conducted to describe the pattern of knowledge, attitude, and practice on food safety among high school students in Jatinangor.

Methods: One hundred and two respondents were involved in this study. The data were collected from the high school students in Jatinangor, West Java from August to November 2013 through the methods of questionnaire after the informed consent was obtained from the respondents. The questionnaire was translated from the Five Keys to Safer Food Manual by World Health Organization. The collected data were then presented in percentage.

Results: Overall, $60.78 \%$ of respondents had moderate knowledge, $85.29 \%$ had good attitude, and $71.57 \%$ had good practice in food safety. Among the five main points on food safety in all aspects, most of the respondents were unaware of the safe temperature to store food; hence, they did not practice it.

Conclusions: Even though most of the students have the knowledge, attitude, and practice on food safety, a need for relevant and motivating education should be performed for spesific indicators of food safety. [AM].2016;3(2):206-11]
\end{abstract}

Keywords: Attitude, food safety, high school students, knowledge, practice

\section{Introduction}

Food is a product that is rich of nutrients required by microorganisms and may be exposed to contamination due to the changes in food production, handling, storage, and preparation techniques as well as eating habits. ${ }^{1}$ Food safety is defined as the confidence level that food will not cause sickness or harm to consumer when it is prepared, served, and eaten according to its intended use. ${ }^{2}$ Contaminated raw food, inadequate cooking, and consumption of food from an unsafe source are factors associated with food-borne diseases in homes, restaurants, school canteen, and street.

Little interest has been given to school students' understanding of safe food-handling. One of the many reasons to highlight this issue is because high school students represent an important population; they will be responsible soon for food preparation for themselves and others. In addition, most of high school students nowadays take a part time job in fast food restaurant to earn extra pocket money. At home, most parents work until late hours, so their children tend to prepare their own food. Therefore, the knowledge (K), attitude (A) and practice (P) on food safety among the high school students are very important. They need to have the right mindset because they are the future food handlers.

In developed countries, a lot of studies about this topic have been conducted among university students, adults, and food hawkers. ${ }^{3-5}$ Studies on knowledge, attitude, and practice on food safety among high school students are scarce. ${ }^{6,7}$ On the other hand, in Indonesia, this study has not been widely studied. In regard to this, a study was performed to describe the pattern of knowledge, attitude, and practice on food safety among high school students in Jatinangor.

Correspondence: Hamizah Sabrina Binti Ahamad Naina, Faculty of Medicine, Universitas Padjadjaran, Jalan Raya Bandung-Sumedang Km.21, Jatinangor, Sumedang, Indonesia, Phone: +6287827571484 Email: sabrina.naina@gmail.com 


\section{Methods}

A descriptive study was conducted to determine the knowledge, attitude, and practice on food safety among high school students in Jatinangor, West Java from August to November 2013. A total of 102 respondents were selected from four high schools; Senior High School (Sekolah Menengah Atas, SMA) PGRI Jatinangor, Vocational School (Sekolah Menengah Kejuruan, SMK) Darul Fatwa, Sekolah Menengah Atas Plus AL-Falah, and Public Senior High School (Sekolah Menengah Atas Negeri, SMAN) Jatinangor. Four schools were chosen out of 10 schools using random sampling. The numbers of student chosen from each school were calculated using proportion method. The inclusion criteria were students attending the four schools respectively and the exclusion criteria were students who did not attend school on the day questionnaires were distributed.

A self-administered questionnaire for this study was prepared based on World Health Organization (WHO) food safety questionnaire. The modified questionnaire included four parts. The first part has been designed to obtain information about the demographic characteristics of the respondents. The second part consisted of 10 questions covering aspect of knowledge about food safety (keep clean, separate raw and cooked, cook thoroughly, keep food at safe temperatures and use safe water and raw material). The students were asked to choose from two options; true or false. The third and four parts consisted of 8 questions consecutively on attitude and practice towards food safety. Respondents were asked to choose from among three options; agree, disagree, or do not know, to reduce response bias on the attitude section. For the practice section, respondents were asked to indicate their level of agreement to the statements using five-point rating scale ( 5 =always, $4=$ most times, $3=$ =sometimes, $2=$ not often, $1=$ never).

The reliability and validity of the food safety questionnaire designed were determined by preliminary study on 30 respondents. These respondents were not included in this study. By using Cronbach Alfa test, the reliability coefficient test on knowledge, attitude, and practice was $0.760,0.938$ and 0.840 respectively after several questions were modified to improve clarity.

Level of knowledge was described using on Guttman scale. Level of attitude and practice used the score range made from the minimum and maximum score. This study was conducted with ethical clearance from the Health Research Ethics Committee of the Faculty of Medicine Universitas Padjadjaran and under permission from Jatinangor authorities.

\section{Results}

There were 45 male students and 57 female students who participated in this study. Majority of the students were 17 years old (Table 1).

Table 1 Characteristics of Subjects

\begin{tabular}{|c|c|c|}
\hline Variables & Numbers of Student (N) $(n=102)$ & Percentage (\%) \\
\hline \multicolumn{3}{|l|}{ Sex } \\
\hline Male & 45 & 44.12 \\
\hline Female & 57 & 55.88 \\
\hline \multicolumn{3}{|l|}{ Age (Years) } \\
\hline 16 & 34 & 33.33 \\
\hline 17 & 62 & 60.78 \\
\hline 18 & 6 & 5.88 \\
\hline \multicolumn{3}{|l|}{ School } \\
\hline SMA PGRI Jatinangor & 9 & 8.82 \\
\hline SMK Darul Fatwa & 19 & 18.63 \\
\hline SMA Plus Al-Falah & 9 & 8.82 \\
\hline SMAN Jatinangor & 65 & 63.73 \\
\hline
\end{tabular}


Table 2 Food Safety Knowledge in Senior High School Students in Jatinangor

\begin{tabular}{lcc}
\hline \multirow{2}{*}{ Statement } & \multicolumn{2}{c}{ Responses N (\%) } \\
\cline { 2 - 3 } & True & False \\
\hline It is important to wash hands before handling food (1) & $101(99.02)$ & $1(0.98)$ \\
Wiping cloths can spread microorganisms (2) & $97(95.10)$ & $5(4.90)$ \\
The same cutting board can be used for raw and cooked foods & $34(33.33)$ & $68(66.67)$ \\
provided if it looks clean (3) & & \\
Raw food needs to be stored separately from cooked food (4) & $101(99.02)$ & $1(0.98)$ \\
Cooked foods do not need to be thoroughly reheated (5) & $57(55.88)$ & $45(44.12)$ \\
Cooked meat can be left at room temperature overnight to cool & $79(77.45)$ & $23(22.55)$ \\
before refrigerating (6) & & \\
Cooked food should be kept very hot before serving (7) & $75(73.53)$ & $27(26.47)$ \\
Refrigerating food only slows bacterial growth (8) & $11(10.78)$ & $91(89.22)$ \\
Safe water can be identified by the way it looks (9) & $15(14.71)$ & $87(85.29)$ \\
Wash fruit and vegetables (10) & $101(99.02)$ & $1(0.98)$ \\
\hline
\end{tabular}

Majority of the respondents $(99.02 \%)$ answered correctly for item 1, 4, and 10 which indicated that they realized the importance of hand washing, separation of raw and cooked food, and that fruit and vegetables need to be washed. However, there were very low percentage of those who answered correctly for item 6 and 8 which only reached about $22.55 \%$ and $10.78 \%$ respectively. This condition showed that many students did not know how to keep food at safe temperature
(Table 2).

There were $61.76 \%$ of the students washed their hands before and during food preparation. Nevertheless, almost one third $(32.46 \%)$ of the students did not practice to keep leftover cooked meals in a cool place after two hours (Table 4).

This study discovered that from all of the respondents, most of them had moderate knowledge of food safety, but good attitude and practice (Table 5).

Table 3 Food Safety Attitudes in Senior High School Students in Jatinangor

\begin{tabular}{lccc}
\hline \multicolumn{1}{c}{ Statement } & \multicolumn{3}{c}{ Responses N (\%) } \\
\cline { 2 - 4 } & Agree & Not Sure & Disagree \\
\hline $\begin{array}{l}\text { Frequent hand-washing during food preparation is worth } \\
\text { the extra time (1) }\end{array}$ & $94(92.16)$ & $7(6.86)$ & $1(0.98)$ \\
$\begin{array}{l}\text { Keeping kitchen surfaces clean reduces the risk of illness } \\
\text { (2) }\end{array}$ & $100(98.04)$ & $2(1.96)$ & $0(0.00)$ \\
$\begin{array}{l}\text { Keeping raw and cooked food separated helps to prevent } \\
\text { illness (3) }\end{array}$ & $76(74.51)$ & $25(24.51)$ & $1(0.98)$ \\
$\begin{array}{l}\text { Using different knives and cutting board for raw and } \\
\text { cooked food is worth the extra effort (4) }\end{array}$ & $80(78.43)$ & $18(17.65)$ & $4(3.92)$ \\
$\begin{array}{l}\text { Soups and stews should always be boiled to ensure safety } \\
\text { (5) }\end{array}$ & $62(60.78)$ & $34(33.33)$ & $6(5.88)$ \\
$\begin{array}{l}\text { I think it is unsafe to leave food out of the refrigerator for } \\
\text { more than two hours (6) }\end{array}$ & $29(28.43)$ & $65(63.73)$ & $8(7.84)$ \\
$\begin{array}{l}\text { Inspecting food for freshness and wholesomeness is } \\
\text { valuable (7) }\end{array}$ & $97(95.10)$ & $5(4.90)$ & $0(0.00)$ \\
$\begin{array}{l}\text { I think it is important to throw away food that has reached } \\
\text { its expiry date (8) }\end{array}$ & $92(90.20)$ & $6(5.88)$ & $4(3.92)$ \\
\hline
\end{tabular}


Table 4 Food Safety Practices in Senior High School Students in Jatinangor

\begin{tabular}{|c|c|c|c|c|c|}
\hline \multirow{2}{*}{ Statement } & \multicolumn{5}{|c|}{ Responses N (\%) } \\
\hline & Always & Most times & Sometimes & Not often & Never \\
\hline $\begin{array}{l}\text { I wash my hands before and during food } \\
\text { preparation (1) }\end{array}$ & $63(61.76)$ & $15(14.71)$ & $24(23.53)$ & $0(0.00)$ & $0(0.00)$ \\
\hline $\begin{array}{l}\text { I clean surfaces and equipment used for food } \\
\text { preparation before re-using on other food } \\
\text { (2) }\end{array}$ & $58(56.86)$ & $21(20.59)$ & $22(21.57)$ & $1(0.98)$ & $0(0.00)$ \\
\hline $\begin{array}{l}\text { I use separated utensils and cutting boards } \\
\text { when preparing raw and cooked food ( } 3 \text { ) }\end{array}$ & $29(28.43)$ & $22(21.57)$ & $34(33.33)$ & $9(8.82)$ & $8(7.84)$ \\
\hline $\begin{array}{l}\text { I separate raw and cooked food during } \\
\text { storage (4) }\end{array}$ & $56(54.90)$ & $26(25.49)$ & $16(15.69)$ & $3(2.94)$ & $1(0.98)$ \\
\hline $\begin{array}{l}\text { I reheat cooked food until it is piping hot } \\
\text { throughout (5) }\end{array}$ & $37(36.27)$ & $24(23.53)$ & $32(31.37)$ & $6(5.88)$ & $3(2.94)$ \\
\hline $\begin{array}{l}\text { After I have cooked a meal, I store any } \\
\text { leftovers in a cool place within } 2 \text { hours (6) }\end{array}$ & $14(13.73)$ & $11(10.78)$ & $44(43.14)$ & $14(13.73)$ & $19(18.63)$ \\
\hline $\begin{array}{l}\text { I check and throw away food beyond expiry } \\
\text { date (7) }\end{array}$ & $62(60.78)$ & $20(19.61)$ & $7(6.86)$ & $10(9.80)$ & $3(2.94)$ \\
\hline $\begin{array}{l}\text { I wash fruit and vegetables with safe water } \\
\text { before eating them (8) }\end{array}$ & $79(77.45)$ & $13(12.75)$ & $7(6.86)$ & $2(1.96)$ & $1(0.98)$ \\
\hline
\end{tabular}

Table 5 Level of Knowledge, Attitude, and Practice on Senior High School Students in Jatinangor

\begin{tabular}{lccc}
\hline \multirow{2}{*}{ Aspect } & \multicolumn{3}{c}{ Number of students N (\%) } \\
\cline { 2 - 4 } & Poor & Moderate & Good \\
\hline Knowledge & $18(17.65)$ & $62(60.78)$ & $22(21.57)$ \\
Attitude & $0(0.00)$ & $15(14.71)$ & $87(85.29)$ \\
Practice & $1(0.98)$ & $28(27.45)$ & $73(71.57)$ \\
\hline
\end{tabular}

\section{Discussions}

Senior high school students in selected schools demonstrated that they had basic knowledge on food safety. About $99.02 \%$ of the respondents answered correctly that it was important to wash hands before handling food. This was supported by a previous study that was conducted in Malaysia ${ }^{8}$ where 93.9\% answered correctly on personal hygiene. Hand washing has been shown to reduce the risk of diarrhea disease in child care institutions ${ }^{9}$ and can certainly do the same in school. As for practice, $61.76 \%$ 'always' and $14.71 \%$ 'most of the times' wash their hands before and during food preparation. Many previous studies proved that it is crucial to practice self-hygiene especially hand hygiene because hand is the major agent that transmits microorganisms and intestinal parasites to foods. ${ }^{10}$

However, there were a few differences between the respondents' knowledge and their attitude towards food safety. For instance, for item 4 on knowledge and item 3 on attitude, it was stated that $99.02 \%$ answered correctly that raw food needed to be stored separately from cooked food. However, only 74.51\% agreed to the statement that keeping raw and cooked food separated helped preventing illness respectively. This evidently showed that even though respondents had the understanding on the specific material, they were not willing to practice it in daily life. This corresponded perfectly with their practice as well, where only $54.90 \%$ 'always' separated raw and cooked food during storage. Another study also revealed that although respondents demonstrated significant knowledge on good personal hygiene, it is not always done into 
good practice. It was also stated that although many youth reported that they have been taught how to prevent food poisoning, they reported that they do not always practice safe food handling because of barriers, such as hunger (for example, too hungry to spend time on precautionary steps). ${ }^{11}$ In addition, the presence of parents appears to be a cue to perform safe food handling procedures, whereas in the absence of parents presents a temptation to neglect these procedures. ${ }^{11}$ Some find the topic irrelevant and not interesting as well as peer pressure (for example, peers are important, so if peers do not practice safe food handling habits, they will also comply in order to fit in). ${ }^{11}$

Respondents seem not to know about keeping food at the safe temperature. For item 6 and 8 on knowledge, about 77.45\% answered wrong stating that cooked meat can be left at room temperature overnight to cool before refrigerating and only $10.78 \%$ answered correctly stating that refrigerating food slows bacterial growth respectively. This trend was seen in the attitude and practice section regarding the similar questions, whereby only $28.43 \%$ presumed it was unsafe to leave food out for more than two hours and only $13.73 \%$ 'always' stored leftover food in the refrigerator within two hours. This was also seen in previous study where only $28 \%$ of the respondents managed to prove that they know the right temperature for storage of hot and cold ready to eat foods. ${ }^{8}$ This result was also supported by Bas et al. ${ }^{12}$ that reported the knowledge of critical temperatures of these aspects are low among their respondents.

Overall, respondents' knowledge is moderate (60.78\%), but they have good attitude $(85.29 \%)$ and good practice $(71.57 \%)$. These findings were consistent with previous study as well. Respondents were reported to have high confidence levels in their ability to engage in safe food handling practices, but their knowledge levels indicate otherwise. ${ }^{13}$ According to Byrd-Bredbenner et al. ${ }^{11}$, their data also indicated that youth have broad knowledge base related to safe food handling. ${ }^{11}$ However, the data also suggested that this knowledge was primarily at the knowledge (recall) level of cognitive domain with limited comprehension as to why safe food handling was important and how to practice safe food handling. ${ }^{11}$

The limitation of this study was that the respondents answered the questions subjectively. Although the questionnaire was anonymous and the participation was voluntarily, however, some of the questions may have been answered dishonestly. This issue may raise the possibility of measurement bias.

It can be concluded that most of the students have the knowledge, attitude, and practice on food safety that should be enhanced. Food safety programs need to be fun, engaging, visually intense and hands on learning that incorporates technology. According to Health Belief Model, knowledge affects beliefs related to perceived susceptibility and severity of disease, benefits of and barriers to practicing preventive health behaviors and self-efficacy. ${ }^{14}$ Therefore, education materials should be developed to assist them in building a solid knowledge base and integrate appreciation for why food safety is imperative, so they would become keen and able to practice safe food handling on their own accord. The value of food safety education for this group is crucial not only because they are preparing food now, but also they will have increase food preparation responsibilities in the future. It will be a good investment that would progress into adulthood and can benefit those around them.

\section{References}

1. Codex Alimentarius Comission, FAO, WHO. Food hygiene. 4th ed. Rome: Food and Agriculture Organization of the United Nations; 2009.

2. WHO. Five keys to safer food manual. Switzerland: Department of Food Safety, Zoonoses and Foodborne Diseases; 2006.

3. Sharif L, Al-Malki T. Knowledge, attitude and practice of Taif University students on food poisoning. Food Control. 2010;21(1):55-60.

4. Abdul Patah MOR, Issa ZM, Nor KN. Food safety attitude of culinary arts based students in Public and Private Higher Learning Institutions (IPT). International Education Studies. 2009;2(4):168-78.

5. Turnbull-Fortune S, Badrie N. Perception, attitude and practices to food Safety among university students living in residence halls, Trinidad, West Indies. Online Int J Food Sci. 2012;1(1):1-11.

6. Norazmir MN, Hasyimah MAN, Shafurah AS, Sabariah BS, Ajau D, Norazlanshah H. Knowledge and practices on food safety among secondary school students in Johor Bahru, Johor, Malaysia. Pak J Nutr. 2012;11(2):110-5.

7. Yoon HJ, Yoon KS. Elementary school 
students' knowledge, behavior and request for educational method associated with food safety. J Korean Diet Assoc. 2007;13(2):169-82.

8. Nee SO, Sani NA. Assessment of Knowledge, attitudes and practices (KAP) among food handlers at residential colleges and canteen regarding food safety. Sains Malaysiana. 2011;40(4):403-10.

9. Xavier CAC, Oporto CFO, Silva MP, Silveira IA, Abrantes MR. Prevalência de Staphylococcus aureusemmanipuladores de alimentos das crechesmunicipais da cidadedo Natal/RN. Rev Bras Anal Clin. 2007;39(3):165-8.

10. Aarnisalo K, Tallavaara K, Wirtanen G, Maijala R, Raaska L. The hygienic working practices of maintenance personnel and equipment hygiene in the Finnish food industry. Food Control. 2006;17(12):1001-11.
11. Byrd-Bredbenner C, Abbot JM, Quick V. Food safety knowledge and beliefs of middle school children: implications for food safety educators. Journal of Food Science Education. 2010;9(1):19-30.

12. Bas M, Ersun AS, Kivanc G. The evaluation of food hygiene knowledge, attitudes and practices of food handlers in food businesses in Turkey. Food Control. 2004;17(4):317-22.

13. Stein SE, Dirks BP, Quinlan JJ. Assessing and addressing safe food handling knowledge, attitudes, and behaviors of college undergraduates. Journal of Food Science Education. 2010;9(2):47-52.

14. Champion VL, Skinner SC. The health belief model. In: Glanz K, RimerBK, Viswanath $\mathrm{K}$, editors. Health behavior and health education. Theory, research and practice. 4th Ed. San Francisco, California: JosseyBass; 2008. 